\title{
Ethnobotany of Tl'azt'en Nation: Plant Use and Gathering Site Characteristics
}

\author{
Leona R. Shaw, Jane P. Young \\ Author Addresses: Ecosystem Science and Management Program University of Northern British Columbia, 3333 University \\ Way, Prince George, BC V2N 4 Z9. \\ Ishaw@unbc.ca
}

Received: June 8, 2011

Volume 3:1-12

Published: March 7, 2012

(C) 2012 Society of Ethnobiology

Abstract: Aboriginal people have intimate and venerable relationships with the environment, and plants were and still are important for food, medicine, and cultural purposes. The present research is a collaborative project between Tl'azt'en Nation (located in northcentral British Columbia, just north of Fort St. James) and the University of Northern British Columbia (UNBC). The objectives of the study were to collect Traditional Ecological Knowledge (TEK) to gain an understanding of the criteria for gathering individual plants for food or medicine use, and to understand why traditional plant gathering sites may fall out of use. Multiple methods were used to gather information from knowledgeable Tl'azt'enne community members including focus groups, interviews, and field trips. Community members possess deep understandings of plants and their gathering sites. People's concerns include the loss of TEK and changing landscapes due to the effects of disturbances on their lands. The knowledge gathered and documented throughout the study can be used to promote the preservation of the culture and language of Tl'azt'en Nation.

Key words: Traditional Ecological Knowledge (TEK), Ethnobotany, Ethnobiology, Tl'azt'en Nation, Plant gathering sites

\section{Introduction}

The Dakelh, or Carrier, people of northcentral British Columbia (BC) see the forest as an integral part of their history and tradition, and several plants from the spruce forest are medicinally important to them (RitchKrc et al. 1996). Sophie Thomas, who passed away in March of 2010, was a beloved and renowned Healer and Elder of the Sai'Kuz First Nation that is part of the Dakelh located near Vanderhoof. Her knowledge of medicinal plants and medicines is part of a vast traditional knowledge about the environment and its people. Sophie was always a keen observer of the natural world, and had seen changes in that world over her lifetime. She was concerned about the destruction of habitat and the accumulation of contaminants (Young and Hawley 2010).

The present study further documents the ethnobotany of the Dakelh people and the traditional ecological knowledge (TEK) of Tl'azt'en (Shaw 2010). The objectives of this research are to gain an understanding of the criteria for gathering individual plants for food or medicine, and to identify reasons why traditional plant gathering sites may fall out of use. Over the last several decades, the land and people of
Tl'azt'en Nation have been considerably affected by industrial developments, such as the establishment of a mercury mine at Pinche Lake in the 1940s, the construction of a railroad line by Pacific Great Eastern Railway Company in the 1970s, and the development of the forestry industry (Morris and Fondahl 2002). This study provides ethnobotanical data that can be incorporated into protection and measurement as strategies necessary for ensuring the continuation of plant gathering activities and conservation of sites. It was important to all involved in this research to document quotes by Tl'azt'en community members (in addition to providing data in tabular form), in efforts to present their knowledge in its cultural context.

\section{Methods}

This research was part of a larger CommunityUniversity Research Alliance (CURA) project made up of team members from Tl'azt'en Nation and the University of Northern British Columbia (UNBC) (Fondahl et al. 2009). Tl'azt'en (People by the Edge of the Bay) are Athapaskan-speaking people (Brown 2002). The name "Carrier" was introduced through a European explorer, but in their own language, they 
refer to themselves as Dakelh (We Travel by Water) (CSTC 2007). They inhabit approximately $6500 \mathrm{~km}^{2}$ of land in northcentral BC, about $65 \mathrm{~km}$ north of Fort St. James (Tl'azt'en Nation 2009). Tl'azt'en Nation is now comprised of thirty-five reserves, ranging between 0.4 and 817 ha in size, that are scattered throughout their traditional territory (Morris 1999). Tache is the administrative centre and the most populated reserve (Karjala 2001). Most of their on-reserve population resides in the three main settlements of Tache, Binche, and Dzitlainli (Grainger, Sherry and Fondahl 2006).

Tl'azt'en Nation is located in the northern part of the Interior Plateau region, bounded on the west by the Coast Mountains, on the north by the Omineca Mountains, and on the east by the Rocky Mountains (Brown 2002). The region is dominated by the SubBoreal Spruce (SBS) biogeoclimatic zone with some areas covered by Mountain Hemlock $(\mathrm{MH})$ and Engelmann Spruce-Subalpine Fir (ESSF). Upland coniferous forests dominate the sub-boreal landscape. The Nechako-Fraser basin is in the south and the Finlay, Parsnip and Peace Rivers in the north, with the watersheds of the Nass and Skeena rivers lying along the western edge. This region contains a number of large natural lakes (Babine, Stuart, and Takla) and human-made reservoirs (Cheslatta/Murray and Williston). The climate is continental with long, cold winters and short summers with relatively long, warm days. Overall, the region has relatively low precipitation (Brown 2002).

Before we began our study, the Tl'azt'en Nation's Band Council Resolution (BCR) and the UNBC Research Ethics Board (REB) agreed that our research was ethical. Each of the research participants granted their written consent and approved of the research methods, recordings and publication of the results, in accordance with the procedures outlined in the ethics approval. In the initial phase of the study, Shaw (the lead researcher) attended several community events and activities such as Language and Culture meetings, Community Day events, an Elder's retreat, and a children's science camp. This allowed Tl'azt'en Nation community members to become familiar with her, and for her to gain some understanding of Tl'azt'en Nation culture.

We held two meetings prior to interviews and asked community members what they thought the project goals, outcomes, and products should be; this ensured that the research would be beneficial and relevant for Tl'azt'en Nation. Ten participants (6 women and 4 men) were selected for this study based on a systematic, peer-reference method (Davis and Wagner 2003). These participants chose thirty-two plants that they thought were important for food/medicine uses; this list was reduced to fifteen plants by the participants to make the project more manageable (Supplementary Table).

Before the interviews began, a detailed "survey" was prepared and acted as a template or type of questionnaire for Shaw to use when interviewing the participants. Questions were related to the uses of plants for food and medicine, information about the plant gathering sites, and any concerns participants may have about traditional plant use and their gathering sites. Dakelh names were used first as a methodological consideration, as there may not be a one to one correspondence between scientific botanical taxa and indigenous plant taxa (Johnson Gottesfeld 1993). The survey questions were pre-tested before the interviews were conducted (Halcomb et al. 2007).

One-on-one interviews with each participant were held in Tache or at the John Prince Research Forest (JPRF) office in Fort St. James. Shaw asked openended, informal interview questions in English following the surveys. The responses were given in either English or Dakelh, whichever was more comfortable for the participant. A researcher, who was also fluent in Dakelh, attended each of the interviews. During the interviews, participants were shown pictures of each of the plants; this was done to help trigger participants' memories and to ensure that both the researcher and participants were referring to the same species (Miranda et al. 2007). Shaw held two field sessions during which she went out into Tl'azt'en territory with participants and other interested community members. Voucher specimens were collected for each plant and samples were gathered to distribute to community members who were unable to attend the field interviews. All focus group meetings and interviews were audio and video recorded. Researchers discussed the recording devices at each event, and asked participants if they were comfortable with the recording methods. The audio recordings were used to create verbatim transcripts. As per Tl'azt'en community norms, team members expected research events to be recorded for archival and educational purposes. During the interviews, the researchers filled out the "survey" by hand and additional notes were taken. The field sessions were not video-recorded, but Shaw took field notes. All audio and video recordings, and hand-written notes, are 


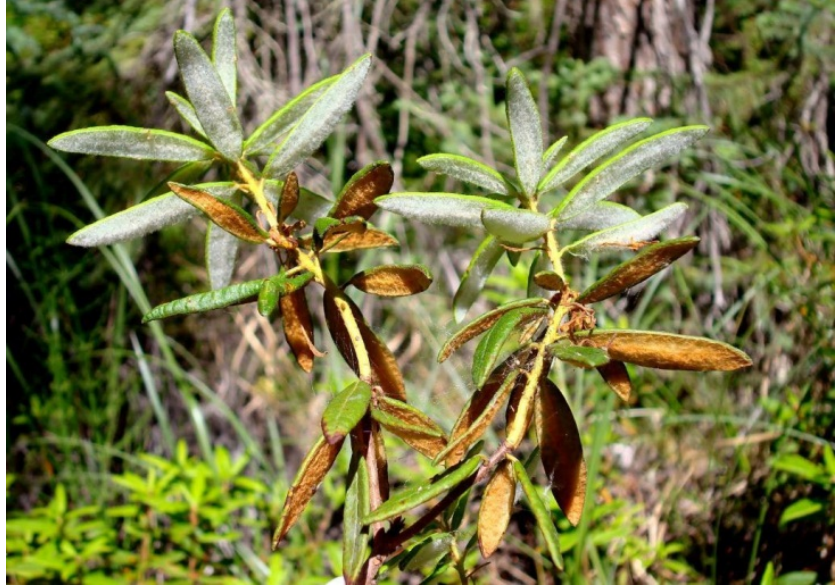

Figure 1. An important medicinal plant, ludi musjek (Ledum groenlandicum).

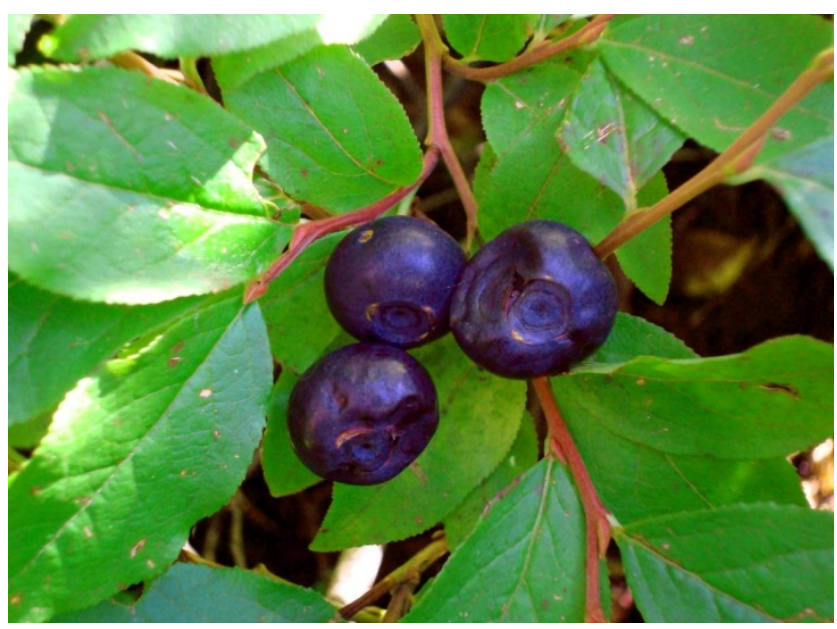

Figure 2. An important food plant, duje (Vaccinium membranaceum).

presently archived with Tl'azt'en Nation and at UNBC. Shaw transcribed interviews manually with the assistance of a Tl'azt'en research assistant. Transcripts included contextual information such as pauses, interruptions (such as cell phones), and emotions (such as laughing, etc.). When Dakelh was spoken, the Dakelh words and English translations were included in the transcript (the research assistant spoke Dakelh fluently and was capable of all translations). All transcripts were edited for accuracy by Shaw or Tl'azt'en research assistants before they were returned to each participant for verification. The participants either reviewed their written transcripts independently or orally with a research team member, and changes were incorporated.
As with any community-based research project, it is important to create products that are culturally important and useful to the community. We produced a community booklet, a brochure, three community updates, posters, and herbarium specimens. Some participants asked to remain anonymous, therefore, their names have been excluded from all products and deliverables, including this article.

\section{Plants and their Gathering Sites}

All fifteen plants identified by Tl'azt'en Nation as being culturally important were considered to be important medicinally, for example, ludi musjek (Ledum groenlandicum Oeder Ericaceae) (Figure 1). Ten of them were also considered important as food sources, for example, duje (Vaccinium membranaceum Douglas ex Torr. Ericaceae) (Figure 2) (Supplementary Table). Fourteen of the plants are currently being used in the community by at least one of the participants. The only plant which was not actively gathered during this study was chunach'ulh (black birch, Latin name unknown). When Shaw asked one participant, "What other plants were used for medicine?" the response was, "Daja ts'iyawh yoo "unt'oh." ("Well, they are all medicine") (Anonymous). Pierre John, one of the Tla'zt'en participants, explains how plant medicines have been used in the past.

One guy he fell off the cliff up on the mountain, he tried to hang on to the rock, but he started rolling with the rock down the mountain. He rolled right down to the bottom, broke every bone in his body. He had to use balsam (Abies lasiocarpa (Hook.) Nutt. Pinaceae) pitch and red willow (Cornus stolonifera Michx. Cornaceae) for two weeks. They take the pitch out with spoon, and put it in his mouth and swallow it the way it is. They use the red willow as a poultice and over a hole with hot rocks. It took the man two weeks to heal; he used a cane to walk back to the river.

Pierre's son, Simon John, speaks about how plant medicines have helped his Dad.

When my Dad (Pierre John) just about died from ulcers in the 1960s, his brother Louie, Beverly's Dad, they got directions from their Grandma to go get these medicines...the doctor said [Dad] had no hope. They mix dats'an angut (Juniperus communis L. Cupressaceae), kinnikinnick (Arctostaphylos uva-ursi L. Spreng. Ericaceae), red willow and ts'ootsun na too' (A. lasiocarpa blisters). They gave it to him for a whole month and some after that, right 'til today 
he is still living, he's seventy-seven years old. They prove the doctor wrong by mixing these medicines, and one of it was dats'an angut. I think it does a lot to cleanse their blood and their system and probably stop the bleeding in the inner too, we wouldn't know that... lot has to do with that ts'ootsun na too'. A lot more of it should be studied I think.

Participants Issac Felix and Theresa Austin share their stories of medicinal use.

I use it [ningwus] (Shepherdia canadensis Nutt. Elaegnaceae) lots for medicine. I use it every day if I feel bad or something. I just eat soapberries, and right there I feel better. Even if you get heartburn or something you would eat soapberries. (Issac Felix)

A few years ago I made some dunih t'an (A. uva-ursi) for my friend, who was going through the change in life, or hot flashes, and she drank it maybe about a week, three times a day, about one cup, and it really helped. It stopped the hot flashes and cold sweats. (Theresa Austin)

Berries are one of the most significant food sources, which is consistent with other studies conducted in BC. They served as an essential winter food source (Johnson Gottesfeld 1993; Lantz and Turner 2003; Turner 1995) and were also considered to be extremely important in trade and potlatch ceremonies (Thornton 1999; Turner 1995). Berries are also important cultural indicator species for other traditional practices such as fishing for salmon according to Tl'azt'en participant, Paul Williams.

They say the more berry flowers you see in the bush then you know more salmon is going to come. But if you don't see very many white flowers in the bush, like blackberries (Amelanchier alnifolia (Nutt.) Nutt Rosaceae) always got real lots of nice white flowers, you just get a few here and there, that means the salmon is not going to be that great of a run. But now-a-days, with the climate, everything is changing.

Several participants, including Mary Lebrun (quote below), state that most of the plants can be gathered all year round, but are best gathered in the spring (see also Supplementary Table).

I think for most of the plants a good time is spring time. You can gather probably year round, most of the medicine is good year round. If a person really needs it they all go out in the bush and get some. Bring a shovel and like if it's a very sick person that really needs it, they'll go out in the bush until they find it.

When asked where plants were selected from, many Tla'zt'en participants, spoke about the importance of their traditional territory. Parlee et al. (2006) found similar results among the Teetl'it Gwich'in (who live in the Northwest Territories). There were extended family ownership developed around many berry patches, and community members stated that these areas can only be accessed if you are invited. Simon John and Theresa Austin discuss this important rule.

If you want the medicine to work, it should come from your traditional territory (keyoh). My father and grandfather always said, "If you want medicine to work, you have to believe in it, and the person that's making it has to believe it's going to help you". And I strongly believe in that and it's just like permission to go into another man's keyoh (traditional territory), you know. They're the ones that make the medicine and help you out; they know their area more than you do. (Simon John)

Long ago when we used to go out, the last day of school usually or the first weekend after school is done, our family and my Aunts and Uncles with their families would go up to Dzitl'ainli. Because we used to just go to our keyoh to pick whatever grows in our territory. I have never gone onto another person's traditional territory to pick berries, unless we had already asked them for permission (Theresa Austin).

Tl'azt'enne also believe that it is important to gather plants where they are the least disturbed.

The trails leading to all our lakes behind the village are all logged out. We don't go there anymore. We tend to stay away from where it's been logged out. We go further away, if we have to, where it hasn't been logged or sprayed or anything. (Simon John)

If you are picking for medicine it has to be away from people, where they don't walk around or use the area. Most of the medicines are supposed to be like that-away from where people walk around. A few miles out of town or something like that. (Mary Lebrun)

They usually say just where the creek, where the creek's running down on the hillside. And some they pick it up on the mountainside, where's there's nobody around, if you're gonna heal with it. (Helen Johnnie) 
When asked what type of site characteristics Tl'azt'enne select for when gathering food or medicine plants, broad areas of "open" and "forested" were mentioned (Supplementary Table). For example, 'ut'ankal (Rubus idaeus L. Rosaceae) and latalba (Achillea millefolium L. Asteraceae) are gathered in open areas. Dunih t'an (A. uva-ursi) is taken from forest floors. Similar results were found in research with several Dene Nations who inhabit the Canadian northwestern boreal forests in BC (Johnson 2008).

When talking about the various plants, participants would often mention the animals and were aware of the animals' needs as well. Ts'ootsun (A. lasiocarpa) is a food source for moose and $\boldsymbol{k}^{\prime} \boldsymbol{u}$ s (Alnus tenuifolia Nutt. Betulaceae) is food for moose, rabbit and deer (Supplementary Table). Johnson (2008) found that when speaking about habitats that Aboriginal people were greatly aware of the relationships of animals to plants and place. Some Dene described the significance of habitats to animals such as caribou, moose, rabbits and ptarmigan in that there were seasons of animal activity and particular plants were food sources for the animals. Isaac Felix speaks about his awareness of other plant users in the following quote.

And it is not only us who are using it, it's the bears too. Every year there's bears there, and they pick right beside us and they don't bother us. Especially grizzly bears, they don't bother us, they just make funny noises but they don't bother us. We just stay on our own side and they stay on their own side.

Participants often described the location of different plant species as "among [plant name]." For example, dats'an angut (J. communis) is found with dunih t'an (A. wva-ursi), and tsalhtse'(Viburnum edule (Michx.) Raf. Caprifoliaceae) is found among t'ughus (Populus tremuloides Michx. Salicaceae) (Supplementary Table). Johnson (2008) found a common pattern occurring in more than one Athapaskan language. For example, a Kaska Elder is aware of the association of berry species with other vegetation. The speaker places himself in the landscape by referring to a spruce forest as "among the trees" instead of using an abstracted classification that separates environment and speaker (Johnson 2008).

A common theme that arose during the interviews was related to respect for plants and their powers. Even though no direct questions were asked about traditional rituals or prayers, the following statements were made by participants.
Everything that they [the Elders] use to tell us is true. They tell us we have to be careful of what we're going to say when we're going out. Tell us not to say anything to hurt the animals or to hurt the Indian medicine what we going to make. Just like a human being we talk to it: "We want you for medicine and to heal who we are going to make it for." We just talk to them and not laugh about anything like that. (Helen Johnnie)

Before we gather our plants we have to make an offering and talk to it. Give [the plant] an offering of tobacco or, if you don't have tobacco, whatever you have that is handy. Some Elders say even a strand of your hair, you could use that to give to the plant as an offering of thanks for helping. "[I] believe that you are going to help me." Talk to the plant. We tell the plant, "We are going to use you for medicine," and usually what we do is put tobacco on the east side of the plant. (Theresa Austin)

First thing we got to do before they take [the plant], you got to say a little prayer. Right at the bottom of it, they offer tobacco. That's how you have to take it. Can't take it without praying, because people believe that, if you do not pray, it won't help us. So that's how we pick berries or anything like food. (Anonymous)

If I take [a plant] I put tobacco there to pay for it. Just not to take the plants unless I have something to replace it with. (Doreen Austin)

Turner, Ignace, and Ignace (2000) state that it is the respect for all life forms more than any other single concept that distinguishes North American aboriginal belief systems. Many believe that plants are entities having their own intrinsic power to help or heal, or to withhold help, therefore, attitude is important when gathering plants (Johnson 2006). Tl'azt'enne believe in similar values, as communicated by Sophie Monk.

Well, we like to respect all the plants and the little animals. Respect all animals, even if they see a frog. Them young kids, they go fool around with it. Respect everything. Then none of it will ever bother them.

\section{Loss of Plants and Plant Knowledge}

The traditional way for a Tl'azt'enne to learn was through verbal stories and lessons from family, other community members, and Elders out on the land. They believe that the only way to truly learn about Tl'azt'enne traditional knowledge is to connect with the land, know the Dakelh language, and practice the 
culture of 'Tl'azt'en Nation in the forms that were passed down through generations of ancestors. Simon and Pierre John reflect upon the importance of these connections.

We need to reconnect ourselves and our people with the land. A lot of people forget about it and just don't do it anymore. Our Elders don't get around as much as they used to. It's harder for them to go out and teach us, but there's not enough young people willing to learn. If they don't learn now it's going to be forgotten. They need to get out there [on the land] and learn. (Simon John)

I don't know what it is but I know people are going to suffer, certain way. Bad time is coming. That's what makes me feel bad. I'm not worrying about the people. I am worried about the kids. Like me, I had my life. But the younger kids, what are they going to do? They don't know how to set net, how to hunt, how to pick berries, and how to make Indian medicine. (Pierre John)

Sherry et al. (2005) said that the transmission of traditional knowledge and cultural values, restoration of the role of Elders as teachers, increased observational/experiential learning opportunities, and respect for the oral tradition were all important to Tl'azt'enne. Decreased rates of skill and knowledge transmission seen in many Aboriginal communities may be due to the fact that the traditional mode of education that involved learning by watching and apprenticeship is not fully operational in the present day, European educational system. In addition, social changes caused by sedentarization, schooling, and the introduction of television have caused changes in values among younger generations (Ohmagari and Berkes 1997). Tl'azt'enne also expressed concerns for loss of traditional knowledge. They fear that fewer people are spending time in their keyoh and less time learning from the Elders, which are points Simon John conveys in the following statements.

Before it's too late we really need to get all these younger people to reconnect with the land and reconnect with the Elders. Half of it is doing research and the damage that has been done in our area. The new plants that are coming, what kind of effect do they have on ours? We don't know that as a Nation because it's new to us. Logging is new to us. Europeans are new to us. A lot of this stuff our people are getting sick on, we don't know about. It's only by trial and error that they know how to deal with certain things like ulcers and that. They overcome things like that. And another big one is arthritis. That's why they learn how to use devil's club (Oplopanax horridus (Sm.) Miq. Araliaceae). It's a learning process even for me and some of our Elders. A lot of it has to do with alcoholism, you know. A lot of the damage was done to their stomach and they turn a lot of their attention to how to help their innards. There's no answer to it, not in the near future anyway. We need to learn from the Elders as fast as we can so we wouldn't lose touch with the land. We will never get it back.

An example of lost traditional ecological knowledge can be directly seen in this project with chunach'ulh (black birch) (Supplementary Table). The participants selected this plant as one of the most important medicine plants to focus this study on. It is known to be a powerful medicine, but not many people currently use it. Most participants recalled stories of the use of chunach'ulh and the strong medicinal properties it possesses, but did not actually use it themselves. This was because most of participants could not positively identify the plant in the field or from pictures and those that could were no longer able to go into the field. Even though the remaining fourteen plants are currently being used in the community, Tl'azt'enne stressed their concern that the knowledge about them is being lost.

Another concern among Tl'azt'enne is that landscapes are changing in their traditional territory. This is due to disturbances such as logging, but the effect this may have on the plants and gathering sites is unknown. Karjala and Dewhurst (2002) found that Tl'azt'en members perceive that forest management practices over numerous past decades have had significant impacts on the forest ecosystem; these concerns include cleanliness of drinking water and moose meat, and negative effects of clear-cut areas.

Mary Lebrun expresses her worry over use of plants near the mercury mine at Pinche Lake:

Especially if the mining is going to come, you have to fence everything off. Look at that Pinche Mine they had long time ago, the mercury mine. You can't make medicine anywhere near there. It is still going to affect us because the streams are coming from there. Look at Pinche Mine, all the streams they go down to the lake and look at all the people that are dying of cancer. 
"The new plants that are coming, what kind of effect do they have on ours?" This concern of Simon John is not uncommon as some invading species negatively affect human health and wealth directly, while others influence the structure and functioning of ecosystems and the maintenance or restoration of native biological diversity (Vitousek et al. 1997). Although there were no documented invasive species affecting the chosen fifteen plants and their gathering sites, Tl'azt'enne are aware that invasive species exist in the area and that these species can seriously impact their traditional territory's biodiversity. Participants also expressed concern about the effects of climate change on their lands and plants. Indigenous populations of Canada are often more vulnerable to climate change because of their close relationships with the environment (Furgal and Sequin 2006).

As mentioned earlier, the industrial development affecting traditional Tl'azt'en Territory includes the establishment of a mercury mine, the construction of a railroad line, and the development of the forestry industry (Morris and Fondahl 2002). Most medicinal plants, as well as animals, have restricted habitats, usually confined to geographic sites like seasides, riversides, highlands and forest zones. Alteration of local ecosystems due to human activities has resulted in severe constraints on the availability and accessibility of plant and animal species used for medicinal purposes (Anyinam 1995). According to the testimony of many Elders who have witnessed tremendous change in BC landscapes over their lifetimes, most of these species are not as productive or as common as they once were (Austin et al. 2008).

\section{Recommendations for Protection of Traditionally Important Plants and their Gathering Sites}

Knowledgeable Tl'azt'enne who use plants for food and medicine do not seem to have many specific sites where plants must be gathered, as long as they are available in Tl'azt'en Territory in an undisturbed area away from people. However, some plants are gathered in preferred areas, for example, dats'an angut ( $J$. communis) on rock bluffs or hillsides at higher elevations in the mountains and ningwus (S. canadensis) in open areas in valleys or near water (Supplementary Table). This site information will give guidance to foresters when deciding upon best management practices, or more importantly, can provide Tl'azt'en Nation with a set of directives for licensees that operate in their territory so that Tl'azt'enne values are protected.

The fifteen culturally important plants identified by the Tl'azt'enne could be incorporated into landscape- level or site-level criteria for Tl'azt'en Criteria and Indicators (C\&I), and then be measured using indicators of health, abundance, and habitat. Tl'azt'en C\&I may be used for evaluation of existing or future management practices in order to develop management scenarios and for incorporation of alternative perspectives (Sherry et al. 2005). The fifteen plants can be used as values in community-based environmental monitoring studies (CBEM) in an effort to maintain biodiversity in Tl'azt'en Nation's traditional territory. Whatever the formula, forest management activities should be planned and implemented so as to protect or enhance sites of ecological, cultural, and social significance to Tl'azt'en Nation. TEK of Tl'azt'en Nation documented in this study, including plant use data and concerns of loss of plants and gathering sites, will be invaluable in environmental decision making and creating policy. Many challenges lay ahead for the incorporation of TEK in management decisions (e.g. Houde, 2007), but the inclusion of this knowledge and wisdom will undoubtedly aid in understanding environmental issues facing the world today.

\section{Conclusions}

Identifying and recognizing the fifteen plants described in this study as important to Tl'azt'en Nation people. The knowledge of plant gathering criteria will lead to better appreciation of ecological systems, and aid in the preservation of culture, language, and biodiversity. Tl'azt'enne plant gatherers have many concerns about plants, gathering sites, and traditional knowledge about them. It is important to note that, although Tl'azt'enne community members are concerned about the loss of TEK, they realize that the TEK system it is adaptable, as are other knowledge systems. By having TEK recorded in "non-traditional" methods, such as in research projects like this, they are controlling the future and the preservation of their knowledge. Finally, it is crucial to undertake further studies, like the present one, to help preserve and perpetuate TEK of the Dakelh people.

\section{Acknowledgements}

We would like to acknowledge all of the Tl'azt'en community members whose knowledge and patience contributed to this paper. Snalchailya (thank you) to the Elders, community members, and project assistants who shared their time, energy and support throughout this project. In particular, we would like to thank Doreen Austin, Theresa Austin, Isaac Felix, Pierre John, Simon John, Helen Johnnie, Mary Lebrun, Sophie Monk, Paul Williams, and those participants 
who wish to remain anonymous. We are also grateful to Beverly John for her guidance and support throughout the project, and to Beverly Bird and Alex Pierre who assisted in the initial design of the research. We would also like to thank the Social Sciences and Humanities Research Council of Canada (SSHRC) for generously funding this research and the UNBC faculty and staff for their support and resources. Tl'azt'en Nation was invited to review this article as per Tl'azt'en guidelines for conduction of research in Tl'azt'en Territory.

\section{References Cited}

Anyinam, C. 1995. Ecology and Ethnomedicine:

Exploring Links between Current Environmental Crisis and Indigenous Medical Practices. Social Science Medicine 40:321-329.

Austin, M. A., D. A. Buffet, D. J. Nicolson, G. G. E. Scudder and V. Stevens, eds. 2008. Taking Nature's Pulse: The Status of Biodiversity in British Columbia. Biodiversity BC, Victoria, BC.

Brown, D. 2002. Carrier Sekani Self-Government in Context: Land and Resources. Western Geography 12:2167.

CSTC (Carrier Sekani Tribal Council). 2007. A CSTC Background. Available at: http://www.cstc.bc.ca/cstc/7/about+cstc. Accessed on January 15, 2012.

Davis, A. and J. R. Wagner. 2003. Who Knows? On the Importance of Identifying "Experts" when Researching Local Ecological Knowledge. Human Ecology 31:463488.

Fondahl, G., P. Wright, D. Yim, E. Sherry, B. Leon, W. Bulmer, S. Grainger and J. Young. 2009. Co-Managing Research: Building and Sustaining a First NationUniversity Partnership. The Community Development Institute at UNBC. Prince George, BC, Canada.

Furgal, C. and J. Seguin. 2006. Climate Change, Health, and the Vulnerability in Canadian Northern Aboriginal Communities. Environmental Health Perspectives 114:19641970.

Grainger, S., E. Sherry and G. Fondahl. 2006. The John Prince Research Forest: Evolution of a Co-

Management Partnership in Northern British Columbia. The Forestry Chronicle 86:1-12.

Halcomb, E. J., L. Gholizadeh, M. DiGiacomo, J. Phillips and P. M. Davidson. 2007. Literature Review: Considerations in Undertaking Focus Group Research with Culturally and Linguistically Diverse Groups. Journal of Clinical Nursing 16:1000-1011.

Houde, N. 2007. The Six Faces of Traditional Ecological Knowledge: Challenges and Opportunities for Canadian Co-management Arrangements. Ecology and Society 12:34.

Johnson, L. M. 2006. Gitksan Medicinal Plants Cultural Choice and Efficacy. Journal of Ethnobiology and Ethnomedicine 2:29. Doi:10.1186/1746-4269-2-29.

Johnson, L. M. 2008. Plants and Habitats - A Consideration of Dene Ethnoecology in Northwestern Canada. Botany 86:146-156.

Johnson Gottesfeld, L. M. 1993. Plants, Land and People, a Study of Wet'suwet'en Ethnobotany, Master's Thesis, Department of Anthropology, University of Alberta, Edmonton, AB, Canada.

Karjala, M. K. 2001. Integrating Aboriginal Values into Strategic-level Forest Planning on the John Prince Research Forest, Central Interior, British Columbia, Unpublished Master's Thesis, Department of Natural Resources and Environmental Studies, University of Northern British Columbia, Prince George, BC, Canada.

Karjala, M. K. and S. M. Dewhurst. 2002. Including Aboriginal Issues in Forest Planning: A Case Study in Central Interior British Columbia, Canada. Landscape and Urban Planning 64:1-17.

Lantz, T. C. and N. J. Turner. 2003. Traditional Phenological Knowledge of Aboriginal Peoples in British Columbia. Journal of Ethnobiology 23:263-286.

Miranda, T. M., M. C. Amorozo, J. S. Govone and D. M. Miranda. 2007. The Influence of Visual Stimuli in Ethnobotanical Data Collection Using the Listing Task Method. Field Methods 9:76-86.

Morris, P. K. 1999. Negotiating the Production of Space in Tl'azt'en Territory, 1969-1984. Unpublished Master's Thesis, Department of Geography, University of Northern British Columbia, Prince George, BC, Canada.

Morris, P. and G. Fondahl. 2002. Negotiating the Production of Space in Tl'azt'en Territory, Northern British Columbia. The Canadian Geographer 46:108-125.

Ohmagari, K. and F. Berkes. 1997. Transmission of Indigenous Knowledge and Bush Skills among the Western James Bay Cree Women of Subarctic Canada. Human Ecology 5:197-222. 
Parlee, B. F. Berkes and Teetl'it Gwich'in Renewal

Resource Council. 2006. Indigenous Knowledge of

Ecological Variability and Commons Management: A

Case Study on Berry Harvesting from Northern

Canada. Human Ecology 34:515-528.

Ritch-Krc, E. M, S. Thomas, N. J. Turner and G. N. H. Towers. 1996. Carrier Herbal Medicine: Traditional and Contemporary Plant Use. Journal of Ethnopharmacology 52:85-94.

Shaw, L. R. 2010. The Ecology of Food and Medicine Plants and their Gathering Sites as Defined by Tl'azt'en Nation. Unpublished Master's Thesis, Department of Natural Resources and Environmental Studies, University of Northern British Columbia, Prince George, BC, Canada.

Sherry, E., R. Halseth, G. Fondahl, M. Karjala and B. Leon. 2005. Local-level Criteria and Indicators: An Aboriginal Perspective on Sustainable Forest Management. Forestry 78:1-27.

Thornton, T. F. 1999. Tleikw aani, the "Berried" Landscape: The Structure of Tlinglit Edible Fruit Resources at Glacier Bay, Alaska. Journal of Ethnobiology 19:27-48.

Tl'azt'en Nation. 2009. About Us. Available at: http://www.tlc.baremetal.com/About $\% 20$ Us.htm. Accessed on January 15, 2012.
Turner, N. J. 1995. Food Plants of Coastal First Peoples. Royal British Columbia Museum, Vancouver, BC.

Turner, N. J., M. B. Ignace, and R. Ignace. 2000. Traditional Ecological Knowledge and Wisdom of Aboriginal Peoples in British Columbia. Ecological Applications 10:1275-1287.

Vitousek, P. M., C. M. D’Antonio, L. L. Loope, M. Reimanek and R. Westbrooks. 1997. Introduced Species: A Significant Component of Human-Caused Global Change. New Zealand Journal of Ecology 21:1-16.

Young, J. and A. Hawley. 2010. Plants and Medicines of Sophie Thomas. Based on the Traditional Knowledge of Sophie Thomas, Sai'Kuz Elder and Healer. 3rd ed. Available at: http://sophiethomas.org/. Accessed on January 15, 2012.

\section{Biosketches}

Leona R. Shaw has a Masters of Natural Resources and Environmental Studies degree. Her studies focused on ethnobotany and traditional ecological knowledge.

Jane P. Young is an Assistant Professor in the Ecosystem Science and Management Program at the University of Northern British Columbia. 
Table 1: Plants of Tl'azt'en Nation: plant use and gathering site characteristics.

\begin{tabular}{|c|c|c|c|c|c|}
\hline Plant & Uses/Parts Used & Plant Characteristics & Site Characteristics & Time of year & Notes \\
\hline $\begin{array}{l}\text { Ts'ootsun } \\
\text { Abies lasiocarpa } \\
\text { (Hook.) Nutt. } \\
\text { (Pinaceae) } \\
\text { Balsam, sub- } \\
\text { alpine fir }\end{array}$ & $\begin{array}{l}\text { Food-Sap eaten as an energizer } \\
\text { Medicine - Sap/pitch used to treat lung } \\
\text { ailments, colds, and as an antibiotic; } \\
\text { bark boiled and used to treat lung } \\
\text { ailments (coughs and tuberculosis) and } \\
\text { itchy throats; branch tips (buds) used to } \\
\text { treat pneumonia; needles used to heal } \\
\text { sores or burned to freshen the air and } \\
\text { prevent colds }\end{array}$ & $\begin{array}{l}\text { Small to medium sized } \\
\text { younger trees with red } \\
\text { bumps/blisters preferred } \\
\text { (easy to peel); older trees with } \\
\text { smooth bark are also selected }\end{array}$ & $\begin{array}{l}\text { Preference to gather at } \\
\text { higher elevations } \\
\text { (where smaller trees } \\
\text { found) or closer to } \\
\text { water }\end{array}$ & $\begin{array}{l}\text { Spring is best (bark } \\
\text { peels more easily), } \\
\text { but can gather all } \\
\text { year round }\end{array}$ & $\begin{array}{l}\text { Food source for } \\
\text { animals, such as moose }\end{array}$ \\
\hline $\begin{array}{l}\text { Dats'an angut } \\
\text { Juniperus communis } \\
\text { L. } \\
\text { (Cupressaceae) } \\
\text { Juniper }\end{array}$ & $\begin{array}{l}\text { Food- Female cones (bluish berries) } \\
\text { used as a spice, similar to clove } \\
\text { Medicine - Whole branch boiled and used } \\
\text { to treat stomach ailments, coughs, } \\
\text { ulcers, tuberculosis, bronchitis, lung } \\
\text { disease, and chest infections }\end{array}$ & $\begin{array}{l}\text { Most effective when branches } \\
\text { and berries are used together; } \\
\text { branches should be green, and } \\
\text { red and brown branches } \\
\text { should be avoided }\end{array}$ & $\begin{array}{l}\text { Gathered on rock } \\
\text { bluffs or hillsides at } \\
\text { higher elevations in the } \\
\text { mountains; often found } \\
\text { with dunih t'an } \\
\text { (kinnikinnick) }\end{array}$ & $\begin{array}{l}\text { Spring is best for } \\
\text { branches and fall } \\
\text { for berries, but can } \\
\text { be gathered all year } \\
\text { round }\end{array}$ & \\
\hline $\begin{array}{l}\text { K’entsi } \\
\text { Cornus stolonifera } \\
\text { Michx. } \\
\text { (Cornaceae) } \\
\text { Red willow, red- } \\
\text { oiser dogwood }\end{array}$ & $\begin{array}{l}\text { Medicine - Whole branch boiled and used } \\
\text { as a pain killer, aspirin, hair wash, to } \\
\text { treat burns, open sores and cuts, } \\
\text { arthritis, tuberculosis and chest } \\
\text { infections; however, outer red bark } \\
\text { peeling is most commonly used; } \\
\text { branches can be placed over hot rocks } \\
\text { to assist in healing broken bones; buds } \\
\text { used to treat arthritis }\end{array}$ & $\begin{array}{l}\text { Smaller plants with red bark } \\
\text { are preferred for medicine } \\
\text { and are the most effective; the } \\
\text { "cleaner" branches with the } \\
\text { least limbs are also used; } \\
\text { plants with old brown } \\
\text { branches are avoided }\end{array}$ & $\begin{array}{l}\text { Best to gather on sunny } \\
\text { hillsides near creeks }\end{array}$ & $\begin{array}{l}\text { Spring is best, but } \\
\text { can be gathered all } \\
\text { year round }\end{array}$ & \\
\hline $\begin{array}{l}\text { Tsalhtse' } \\
\text { Viburnum edule } \\
\text { (Michx.) Raf. } \\
\text { (Caprifoliaceae) } \\
\text { Cranberry }\end{array}$ & $\begin{array}{l}\text { Food-Berries eaten raw and made into } \\
\text { jam } \\
\text { Medicine-Berries or branches used to } \\
\text { treat stomach ailments, kidney } \\
\text { infections, and the flu; berries used to } \\
\text { treat constipation and clean out your } \\
\text { stomach and kidneys }\end{array}$ & $\begin{array}{l}\text { Best to gather branches when } \\
\text { berries are present }\end{array}$ & $\begin{array}{l}\text { Gathered along shores } \\
\text { in lower elevations; } \\
\text { often found among } \\
\text { t'ughus (poplar) }\end{array}$ & $\begin{array}{l}\text { Best to gather } \\
\text { branches in spring } \\
\text { and berries in late } \\
\text { summer }\end{array}$ & \\
\hline $\begin{array}{l}\text { Ningwus } \\
\text { Shepherdia } \\
\text { canadensis (L.) } \\
\text { Nutt. } \\
\text { (Elaegnaceae) } \\
\text { Soapberry }\end{array}$ & $\begin{array}{l}\text { Food-Berries eaten raw, dried, or made } \\
\text { into Indian ice cream; berries are a good } \\
\text { source of Vitamin C } \\
\text { Medicine - Berries eaten to treat heart } \\
\text { conditions, heartburn, diarrhea, } \\
\text { constipation, stomach ailments (such as } \\
\text { ulcers and cancer), and to cleanse the } \\
\text { blood and kidneys; berries can be put }\end{array}$ & $\begin{array}{l}\text { Best to gather plants with red } \\
\text { ripe berries; older branches } \\
\text { should be avoided }\end{array}$ & $\begin{array}{l}\text { Gathered in open areas } \\
\text { in valleys or near water; } \\
\text { often gathered among } \\
\text { forests that have mix } \\
\text { of pine and poplar }\end{array}$ & $\begin{array}{l}\text { Best to gather } \\
\text { berries in summer } \\
\text { or late summer; } \\
\text { best to gather } \\
\text { branches in spring, } \\
\text { but can be gathered } \\
\text { all year round }\end{array}$ & \\
\hline
\end{tabular}




\begin{tabular}{|c|c|c|c|c|c|}
\hline & into eyes to treat cataracts & & & & \\
\hline $\begin{array}{l}\text { Ludi musjek } \\
\text { Ledum } \\
\text { groenlandicum } \\
\text { Oeder } \\
\text { (Ericaceae) } \\
\text { Labrador tea } \\
\end{array}$ & $\begin{array}{l}\text { Food - Leaves boiled to make tea } \\
\text { Medicine - Leaves boiled and used as a } \\
\text { relaxant or sleeping aid and to treat high } \\
\text { blood pressure and angina (chest pains) }\end{array}$ & $\begin{array}{l}\text { Plants that have large, green, } \\
\text { fresh leaves are preferred }\end{array}$ & $\begin{array}{l}\text { Gathered in swampy, } \\
\text { mossy area at lower } \\
\text { elevations }\end{array}$ & $\begin{array}{l}\text { Best to gather in } \\
\text { spring when plants } \\
\text { are flowering, but } \\
\text { can be gathered all } \\
\text { year round }\end{array}$ & \\
\hline $\begin{array}{l}\text { 'Ut'ankal } \\
\text { Rubus idaeus L. } \\
\text { (Rosaceae) } \\
\text { Raspberry }\end{array}$ & $\begin{array}{l}\text { Food- Berries eaten raw and made into } \\
\text { jam } \\
\text { Medicine - Whole branch (including the } \\
\text { leaves) boiled and used to treat diarrhea, } \\
\text { stomach ailments, ulcers, the flu and to } \\
\text { prevent hemorrhaging after child birth }\end{array}$ & $\begin{array}{l}\text { Younger 'fresher' looking } \\
\text { plants are preferred }\end{array}$ & Gathered in open areas & $\begin{array}{l}\text { Best to gather the } \\
\text { berries in summer; } \\
\text { branches can be } \\
\text { gathered all year } \\
\text { round }\end{array}$ & \\
\hline $\begin{array}{l}\text { Hoolhghulh } \\
\text { Oplopanax horridus } \\
\text { (Sm.) Miq. } \\
\text { (Araliaceae) } \\
\text { Devil's club }\end{array}$ & $\begin{array}{l}\text { Medicine - Outer bark or roots used as a } \\
\text { pain killer and to heal broken bones; } \\
\text { roots ground and used as a muscle rub } \\
\text { Please note: Hoolhghulh is for external } \\
\text { use only and should not be left on a } \\
\text { person for too long }\end{array}$ & $\begin{array}{l}\text { Younger plants are preferred, } \\
\text { as the older ones are too } \\
\text { 'woody' }\end{array}$ & $\begin{array}{l}\text { Gathered in cooler, } \\
\text { damp areas of ridges } \\
\text { that are close to water }\end{array}$ & $\begin{array}{l}\text { Best to gather in } \\
\text { spring, but can } \\
\text { gather in summer } \\
\text { or fall as well }\end{array}$ & \\
\hline $\begin{array}{l}\text { Dunih t’an } \\
\text { Arctostaphylos uva- } \\
\text { ursi (L.) Spreng. } \\
\text { (Ericaceae) } \\
\text { Kinnikinnick }\end{array}$ & $\begin{array}{l}\text { Food- Berries eaten raw } \\
\text { Medicine - Whole branch boiled and is } \\
\text { good for the lungs and to clean out your } \\
\text { system, and can treat colds, tuberculosis, } \\
\text { stomach bleeding and the flu; whole } \\
\text { branch with the roots boiled and used to } \\
\text { treat menopausal symptoms (the change } \\
\text { in life), such as hot flashes and cold } \\
\text { sweats }\end{array}$ & $\begin{array}{l}\text { Green branches with ripe } \\
\text { berries are preferred; plant is } \\
\text { most potent with berries, but } \\
\text { can be used without them }\end{array}$ & $\begin{array}{l}\text { Gathered in rocky area } \\
\text { on forest floor or on } \\
\text { mountain or hillsides; } \\
\text { often gathered with } \\
\text { dats'an angut } \\
\text { (juniper) }\end{array}$ & $\begin{array}{l}\text { Best to gather in } \\
\text { summer when the } \\
\text { berries are ripe, but } \\
\text { can be gathered in } \\
\text { spring and fall as } \\
\text { well }\end{array}$ & \\
\hline $\begin{array}{l}\text { Latalba } \\
\text { Achillea millefolium } \\
\text { L. } \\
\text { (Asteraceae) } \\
\text { Yarrow }\end{array}$ & $\begin{array}{l}\text { Medicine - Whole plant boiled and used } \\
\text { as a diuretic, to treat a sore throat, } \\
\text { stomach ailments, and arthritis; plant } \\
\text { can be rubbed directly onto the skin as a } \\
\text { bug repellant }\end{array}$ & $\begin{array}{l}\text { Plants with white flowers are } \\
\text { selected and brownish ones } \\
\text { are avoided; any plant that } \\
\text { turns brown when boiled is } \\
\text { removed from the pot }\end{array}$ & $\begin{array}{l}\text { Gathered in any open } \\
\text { area }\end{array}$ & $\begin{array}{l}\text { Best to gather in } \\
\text { summer when } \\
\text { flowers are white }\end{array}$ & \\
\hline $\begin{array}{l}\text { K'us } \\
\text { Alnus tenuifolia } \\
\text { Nutt. } \\
\text { (Betulaceae) } \\
\text { Alder }\end{array}$ & $\begin{array}{l}\text { Medicine - Bark ground into a powder } \\
\text { and used for stomach ailments; inner } \\
\text { bark boiled and used to treat ulcers; all } \\
\text { of bark boiled and used to treat sores, } \\
\text { asthma, and chest colds; bark also } \\
\text { chewed to treat the flu }\end{array}$ & $\begin{array}{l}\text { Younger, medium-sized } \\
\text { plants with catkins are } \\
\text { preferred }\end{array}$ & $\begin{array}{l}\text { Gathered in any open } \\
\text { area }\end{array}$ & $\begin{array}{l}\text { Best to gather in } \\
\text { spring when bark is } \\
\text { easier to peel, but } \\
\text { can be gathered all } \\
\text { year round }\end{array}$ & $\begin{array}{l}\text { Food source for } \\
\text { wildlife such as moose, } \\
\text { rabbit, and deer }\end{array}$ \\
\hline $\begin{array}{l}\text { Chundoo } \\
\text { Pinus contorta } \\
\text { Douglas ex } \\
\text { Loudon }\end{array}$ & $\begin{array}{l}\text { Food-Pitch (chun ts'a') eaten; black } \\
\text { tree lichens found on chundoo are } \\
\text { edible as well } \\
\text { Medicine - Pitch used to treat burns and }\end{array}$ & $\begin{array}{l}\text { Younger small or medium- } \\
\text { sized trees are preferred }\end{array}$ & Gathered anywhere & $\begin{array}{l}\text { Best to gather } \\
\text { pitch in spring and } \\
\text { bark in spring or } \\
\text { summer }\end{array}$ & $\begin{array}{l}\text { Severely damaged by } \\
\text { the mountain pine } \\
\text { beetle infestation }\end{array}$ \\
\hline
\end{tabular}




\begin{tabular}{|c|c|c|c|c|c|}
\hline $\begin{array}{l}\text { (Pinaceae) } \\
\text { Jack pine, } \\
\text { lodgepole pine }\end{array}$ & $\begin{array}{l}\text { sores and a pain killer and cold rub; bark } \\
\text { and buds boiled and used for stomach } \\
\text { ailments or as an antibiotic }\end{array}$ & & & & \\
\hline $\begin{array}{l}\text { T'ughus } \\
\text { Populus tremuloides } \\
\text { Michx. } \\
\text { (Salicaceae) } \\
\text { Poplar, trembling } \\
\text { aspen }\end{array}$ & $\begin{array}{l}\text { Food-Sap eaten } \\
\text { Medicine - Bark chewed and applied to } \\
\text { open wounds to stop bleeding; bark also } \\
\text { boiled and used to treat pinworms, } \\
\text { eczema, and ulcers }\end{array}$ & $\begin{array}{l}\text { Young, smaller trees are } \\
\text { preferred }\end{array}$ & $\begin{array}{l}\text { Best to gather in lower } \\
\text { elevations, as bark } \\
\text { tends to be too dry in } \\
\text { higher elevations }\end{array}$ & $\begin{array}{l}\text { Best to gather in } \\
\text { spring or summer, } \\
\text { but can be gathered } \\
\text { all year round }\end{array}$ & $\begin{array}{l}\text { Food source for } \\
\text { beavers }\end{array}$ \\
\hline $\begin{array}{l}\text { Duje } \\
\text { Vacinium } \\
\text { membranaceum } \\
\text { Douglas ex Torr. } \\
\text { (Ericaceae) } \\
\text { Huckleberry }\end{array}$ & $\begin{array}{l}\text { Food-Berries eaten raw and made into } \\
\text { jams and jellies; berries also boiled with } \\
\text { water and used as a syrup for pancakes, } \\
\text { ice cream or cake } \\
\text { Medicine - Berries eaten as an energizer } \\
\text { or used to clean out your system }\end{array}$ & $\begin{array}{l}\text { Plants with green leaves and } \\
\text { newer growth are preferred as } \\
\text { berries tend to grow bigger on } \\
\text { these }\end{array}$ & $\begin{array}{l}\text { Best to gather in open } \\
\text { areas on hillsides in } \\
\text { higher elevations }\end{array}$ & $\begin{array}{l}\text { Best to gathered in } \\
\text { summer when } \\
\text { berries are ripe }\end{array}$ & $\begin{array}{l}\text { Food source for } \\
\text { wildlife such a rabbit, } \\
\text { deer, elk, and bear }\end{array}$ \\
\hline $\begin{array}{l}\text { Chunach'ulh } \\
\text { (latin name } \\
\text { unknown) } \\
\text { Black birch }\end{array}$ & $\begin{array}{l}\text { Medicine - Bark boiled and used to treat } \\
\text { pneumonia; bark also chewed raw to } \\
\text { relieve chest pains or to treat colds }\end{array}$ & Unknown & Unknown & Unknown & $\begin{array}{l}\text { Unable to find it in the } \\
\text { field and positively } \\
\text { identify it; not many } \\
\text { people presently use it; } \\
\text { very difficult to find } \\
\text { and not many people } \\
\text { can positively identify } \\
\text { it }\end{array}$ \\
\hline
\end{tabular}

